August 1973

U.S. ISSN 0084-0793
ITC No. 92

THE LAND TENURE CENTER

310 King Hall

University of Wisconsin

Madison, Wisconsin 53706

CREATING OPPORTUNITIES FOR SMALL FARMERS:

THE: ROLE OF LAND TENURE AND SERVICE INSTITUTIONS*

By

Don Kanel**

*Revised version of a paper prepared for the Purdue Workshop in Small Farm Agriculture, Purdue University, Lafayette, Indiana, November 13-15, 1972 , to be published in Perspectives in Rural Development, eds. Lawrence J. Brainard and Ray Dumett (Purdue University Press, forthcoming).

**Professor of Agricultural Economics and the Land Tenure Center, University of Wisconsin-Madison.

All views, interpretations, recommendations, and conclusions expressed in this paper are those of the author and not necessarily those of the supporting or cooperating organizations. 


\section{CREATING OPPORTUNITIES FOR SMALL FARMERS: \\ THE ROLE OF LAND TENURE AND SERVICE INSTITUTIONS*}

By

\section{Don Kanel**}

This paper is concerned with the institutional organization of the agricultural sector. It deals with two types of institutions: 1) land tenure, including types of tenure and the size distribution of farms, and 2) service institutions performing marketing, processing, credit, research, and extension functions. With respect to the latter, the major issue discussed is whether such services are widely available to all the farmers or whether they are primarily accessible only to the larger farmers.

Under present circumstances of large rates of population growth in the less developed countries, it is important to prevent premature decrease of employment in agriculture, to minimize the stresses due to displacement of workers and increased insecurity of employment, and to achieve a wider distribution of the benefits of development. If larger farmers have a dominant role in adopting new technology, they may displace tenants and workers. A more egali-

*Revised version of a paper prepared for the Purdue Workshop on Small Farm Agriculture, Purdue University, Lafayette, Indiana, November 13-15, 1972, to be published in Perspectives in Pural Development, eds. Lawrence J. Brainard and Ray Dumett (Purdue University Press, forthcoming).

**Professor of Agricultural Economics and the Land Tenure Center, University of Wisconsin-Madison.

I would like to express my appreciation for suggestions, encouragement, and for use of their ideas to my colleagues in the Land Tenure Center, Peter Dorner, Herman Felstehausen, Eugene Havens, David King, Kenneth Parsons, James Scott, and William Thiesenhusen; to John Powell of the Political Science Department of Tufts University; to my wife, Bettina Kanel; and to the Land Tenure Center editor, Jane Knowles. 
tarian land tenure system is likely to decrease labor displacement, but if agricultural development is to be based on small farmers, then the creation of appropriate service institutions becomes crucial.

In many less developed countries, larger farmers do indeed seem better prepared to take advantage of new technology. In Western Europe, outside of Great Britain, nineteenth-century development was accompanied by the breakup of larger farms. However, this breakup occurred in a situation significantly different from current conditions in the IDCs. These differences can be summarized as follows:

I) The large farms of many less developed countries are the historical result of various processes (feudalism, conquest, etc.) which have little to do with economic viability of different sizes of farms. That is, their size is not due to competition between farms in factor and product markets but is due to other causes. However, since such farms exist, they are available to assume a new modernizing role in introducing new technology, infrastructure, and processing. On the eve of rapid economic development such farms are owned by the elite.

2) In European development in the nineteenth century, urbanization and attractive opportunities in industry, commerce, politics, and education drew the elite (as well as new classes) to nonagricultural opportunities, leaving agriculture to the peasants. Absentee ownership is particularly deadening to incentives and initiatives when owners lose interest but continue their ownership. The West European land reforms from the French Revolution on facilitated transfer of ownership from inactive to active managers, though these transfers were also accompanied by voluntary sales. The underlying reasons for this transition were: a) economies of size achievable on family farms and b) greater attractiveness of nonagricultural opportunities for wealth and 
entrepreneurial ability.

3) Development opportunities in the LDCs in the twentieth century (particularly those provided by the Green Revolution) may have a different balance of underlying factors. At a time when nonagricultural opportunities are still limited, the Green Revolution has brought sudden and dramatic increases in income. On larger farms income of the landowner can be increased by mechanization, by displacement of tenants and hired workers, and by active management.

4) In addition, at a time when government agencies, cooperatives, and private marketing firms serving small farmers are poorly developed, actively managed large farms can assume the role of providing services and infrastructure, and aggressively expand into new markets as opportunities develop.

5) Under these circumstances--attractive income opportunities in agriculture and active management on large farms--private operators of large farms will be making crucial decisions about how agriculture is to be modernized. Development is more likely to proceed along a capital--intensive, labor-säving path, increasing the employment problem and concentrating the benefits of development in a few hands. These patterns are directly opposed to the requirements of a situation characterized by much more rapid population growth and more deficient employment opportunities in industry than those which characterized nineteenth-century European development.

However, large scale is not required in order to achieve efficient organization of crop and livestock production. In most types of farming there are no decisive economies of scale for large units, and farms of different size can coexist. In a theoretical sense this assertion means that least-cost production is achievable on a farm by combining the labor force of a farm family 
(approximately two or three man-years per farm) with sufficient land to provide full employment to family labor and capital (1,9). Actually most peasants on minifundia farms have excess labor and insufficient land, and thus they do not appear to achieve a least-cost organization. But in fact they shelter and employ a labor force which has no significant alternative employment opportunity; in effect they come closer to equating the demand for labor with the supply of labor at its opportunity cost than the rest of the economy. As outside employment opportunities improve, these small farms can be expected to adjust themselves to provide incomes equal to new opportunity costs by outmigration of farm people, farm enlargement, and increase in part-time farming (as has happened in the U.S. and Western Europe). The ability of the small farm to participate in development is not adversely affected by sheltering an excess labor force, but instead it depends on two additional conditions: 1) a yieldincreasing technology that is highly divisible, and 2) a structure of related services that is available on equal terms to small farms.

In the developed countries family farms have continued to be important because they have primarily carried out those production functions which are difficult to standardize, difficult to supervise, and which do not lend themselves to division of labor (i.e., biological and seasonal activities). These are residual functions, while other functions have tended to be taken over by separate firms as changing technology has created economies of size, e.g., butter and cheese making, canning of fruits and vegetables, and largescale cattle feedlots. All these activities were formerly within the farm firm. In addition, many new activities have grown up as a result of increased urbanization and such technological change as assembly, grading, storage, and transportation of agricultural commodities, freezing of fruits and vegetables, etc. 
Processing functions have a distinct technology and different economies of size than crop and livestock production. As will be shown below in an illustration drawn from Denmark, peasants in that country made a low quality butter on their own farms. At the same time (approximately the period 1800-1870) larger farms made a higher quality butter, largely because they could afford facilities for cooling milk. Thus in both types of farms butter-making and farming were integrated within the same firms, but production of high quality butter had economies of size too large to be incorporated in a small farm. After 1870 a combination of further changes in technology, institutions, and infrastructure (centrifugal cream separators, cooperative creameries, and better roads) made it more economical for butter-making to be separated from dairy herd. management, and the cooperative creameries provided a market outlet for all dairy farmers large and small.

Thus the ability of the small farm to survive and to participate in development depends not only on its efficiency in crop and livestock production, but also on equal access to market outlets and to other services including infrastructure, credit, extension, and research. The institutional structure of the agricultural sector in the United States, Western Europe, and Japan is based both on family farms to carry on crop and livestock production and on a complex structure of service institutions adapted to the needs of family farms. In this system the responsibilities for research and development, entrepreneurial innovation, and integration of complementary production functions are distributed among many private, cooperative and public agencies with integration achieved by markets, contracts, and membership in cooperatives.

This organization of the agricultural sector on the basis of small farms and required service institutions is not only possible but has proven to be 
highly efficient. The contrast between the organization of industry and of agriculture in the western economies supports this assertion. While industry is dominated by large firms and the integration of many functions within a single firm, in agriculture the firms are small, many functions are performed by different firms, and integration of functions requires market and other linkages between firms. I believe that the reason for this is the absence of significant economies of size combined with difficulties of supervision and centralized large-scale management in most types of crop and livestock production (1). In addition, cooperatives and public agencies have provided efficient service functions. Under such circumstances, where large firms exist in processing, marketing, or supply of farm inputs they have little incentive to integrate into crop and livestock production.

There is, however, a question whether the approach of using small farms and required service institutions is applicable to twentieth-century conditions in many LDCs, particularly in view of the wide gap between the large and small farms that exists in these countries and the more sophisticated technology that is now available. Where large farms already exist and where infrastructure and processing facilities are limited, alternative approaches to agricultural development may seem more feasible. Some processing and infrastructural facilities are likely to be already present on large farms. When new opportunities appear for expansion of agricultural production, large farms may be better able to expand because of the facilities that they have, or b'ecause they are large enough to provide the needed additional infrastructure and processing. Or, from the point of view of public agencies, it is then probably quicker and cheaper to concentrate public research, extension, and investment activities in a manner that supplements facilities on large farms and that fosters increase 
in production primarily on these large farms. Similarly, private marketing firms may find it more attractive to deal primarily with large farms because they offer the required quality of product, because they process the product to the point at which the marketing firm can take it over, or because the product can be obtained from them at a lower cost (for example, by avoiding assembling costs on poor roads from many small farmers.).

Thus the conditions described above discourage a development approach based on small farms, because such an approach seems to require a difficult and costly substitution of new infrastructure and processing facilities for those already existing on large farms. From the point of view of the state, its own efforts would seem larger and the response of other cooperating agencies less certain than if the development strategy depended on working with large farmers.

\section{Illustrative Cases}

Varying conditions creating development opportunities for either small or large farms are illustrated by three case studies described below. The Danish case is one in which new institutions and a new processing technology created development opportunities for small farmers. Under these conditions family farms needed only to concentrate on crop and livestock production activities and became competitive or superior to larger farms. At the same time larger farms suffered from their unattractiveness to hired workers (bad working and housing conditions), and lower incentives for worker productivity, without the offsetting advantages which they had previously when they possessed superior technology and processing facilities.

A. Butter Production in Denmark (15)

Danish land reforms at the end of the eighteenth and beginning of the nineteenth centuries abolished manorial agriculture arid serfdom, and carved out 
peasant farms from parts of the feudal estates, while preserving large farms from the remainder of the estates. After the reforms large farms were worked by hired labor housed in barracks. Further transfer of land to the peasants occurred by voluntary sales supported by special credit programs.

The transition which followed was part of a general Western European shift to greater production of livestock and livestock products as a result of the flood of grain exports from the New World after 1870. In the beginning of this period, large farms made butter of much higher quality than peasant farms. Premium prices for estate butter were as much as double the prices of ordinary farm butter and only estate butter was exported (p. 189). Cooling of milk, sanitary facilities, and expert management were the key factors in butter quality. Large farms had spacious milk cellars, cooled milk with cold water and later with ice, used thermometers, and placed butter production under a daixy manager or a dairywoman ( $p p .188,191$ ). On small farms, cows were plertifuriy fed only in the surmer, milk was left to sit for two days so that cream could be skimmed off, then the cream was left to curdle before churning butter in a hand churn (p. 189).

The transformation had a technological aspect--the centrifugal cream separator--and an institutional aspect--shift of butter-making from the farm to a cooperative creamery. A cooperative creamery provided a separator and cooling facilities so that separation of cream and cooling could occur quickly after milking and delivery of milk from the farms, and it had a trained manager to look after production and quality control. Skim milk was returned to farmers and fed to pigs. By the beginning of the twentieth century "Iandowners were no longer the best farmers and they often had a bad reputation on account of the conditions they offered their laborers, who would in many cases have to live in 
dilapidated landless cottages or in barracks" (p. 271). The number of cooperative dairies increased rapidly from 176 in 1886, 600 in 1890, and 942 in 1900 . As a result "many major dairies were ultimately closed down, the owners joining the cooperative dairies founded and managed by peasants" (p. 198).

\section{B. Green Revolution in Pakistan (6)}

The Pakistani case, described below, differs from the Danish example partly in the absence of service institutions but especially in a much more vigorous response of larger farmers to the opportunities of new technology. In this case the tubewell seems to have become the crucial indivisible unit of capital, but only 6 percent of the farms were large enough to justify investment in a well. However, more than two-thirds of the smaller farmers obtained access to irrigation water by purchasing it or by cooperating to install jointly owned wells. Thus the smaller owner-cultivators did participate in the new opportunities. The major problem was the increased interest of larger farmers in active management of their farms, in mechanization, and in displacing tenants and workers from their farms. It is this increased interest of larger farmers in active mnnagement that contrasts with the rural elite's abandonment of agriculture to the peasants in nineteenth-century European development. I suspect that this contrast is due to much more attrative opportunities in agriculture in Pakistan. The Green Revolution brought about dramatic increases in incomes obtainable from agriculture compared to the still limited nonagricultural opportunities. Also, high price supports, for wheat, availability of credit for purchase of machinery, and undervalued foreign exchange favored mechanization of larger farms (5). These conditions increased the attraction to the rural elite of engaging in agricultural entrepreneurship rather than in continuing as more passive rent-receiving. Iandowners or shifting their energies and wealth to the cities. 
The following information about the impact of the Green Revolution comes from a study by Gotsch of the Sahiwal District in the Punjab area of Pakistan. Output in this area increased at the rate of 7 percent per year in the period 1960-70. There were three waves of innovation:

1) Tubewells-Water availability was increased by 50 percent, and resulted in increased production of sugarcane, cotton, and rice.

2) Seed-Fertilizer Revolution--New wheat varieties were introduced in 1966-67. In three years 90 percent of the acreage of wheat was under improved varieties, fertilizer sales increased more than four-fold, wheat yields were up 60 percent.

3) Mechanization--Yields increased by 10-15 percent, and mechanization made possible an increase in double cropping by speeding up seedbed preparation between growing seasons.

There were 223,000 holdings in the district: 43 percent under 5 acres, 51 percent 5-25 acres, and 6 percent over 25 acres. Gotsch estimated that a farmer needed 30 acres to break even on his investment in a tubcwell, and that at least 40 acres were required to achieve lowest costs from the use of a tubawell. These cost estimates are consistent with the data about well installation. According to a 1965 survey, 4200 wells were installed in the district, 54 percent on farms over 50 acres, 30 percent on farms of 25-50 acres, 16 percent on farms under 25 acres. On this basis about 30 percent of the farms over 25 acres had wells. Smaller farmers either installed jointly owned wells or purchased water. Sixty-eight percent of farmers with less than 25 acres were purchasing water, but the amount of water per acre was only 20 percent of the optimal amount, which may reflect lack of credit (cash payments required for water purchase) or monopoly rents for water.

The initial supply of improved wheat seed went to larger farmers, but within 
two years seed was widely available. In 1970,84 percent of smaller farmers were using high yielding varieties (HYV) and 76 percent were applying fertilizer, but the level of fertilizer use per acre was 60 percent of the optimal amount and was below the amounts used by large farmers.

The economic operation of tractors requires even larger farms than does the use of tubewells. Gotsch estimated that 45 acres is the break-even size of farm, and that 100 acres are required for least-cost operation with tractors. The purchase of tractors in the district was leading to the eviction of tenants from larger farms. The drive to use the full range of new technology--tractors, tubewells, fertilizer, and the new wheat varieties--came primarily from farmers operating farms of 50 to 200 acres, not from the very large landowners with 200 to 500 acres. Using a somewhat different grouping of sizes of farms, the study of the Sahiwal District shows that in the period 1950-69, farmers with 50 to 100 acres increased their holdings by purchasing additional land, while farmers with both larger and smaller holdings decreased the amount of land that they operated.

Smaller farmers made more limited use of mechanization. Thirty-one percent of farmers with less than 25 acres hired tractor services, but all such farmers retained the full complement of bullocks and equipment. Thus they did not avail themselves of the potential gain of eliminating fodder production for the maintenance of bullocks.

\section{Dualistic Agriculture in Central America (12, 13)}

The agriculture of Central America (Guatemala, El Salvador, Honduras, Nicaragua, and Costa Rica) is markedly dulistic. Of major interest for the argument of this paper is the integration of processing facilities with larger farms, and the ability of larger farms to shift quickly to satisfy new markets. Large farms in Central America dominate the production of the traditional export 
crops, coffee and sugarcane, as well as the newer exports of cotton and beef, and foreign-owned plantations control production of bananas. Market supplies of domestic food crops--corn, rice, wheat, sorghum, and beans--have traditionally come from smaller farmers.

In the period 1950-67 rapid expansion in export crop production occurred utilizing labor-saving technologies. Between 1950 and 1964 Guatemalan coffee output increased by 157 percent (coffee acreage increased by 85 percent) but employment increased by only 7 percent. Expansion of cotton cultivation in Nicaragua occurred in an area previously occupied by livestock ranches, on which portions of land were leased to small farmers. These former tenants were displaced by the shift to cotton. Mechanized land preparation and chemical weed control in cotton cultivation required little permanent labor, but cotton harvesting was a labor-intensive seasonal activity. However, when displacement of resident labor from a zone resulted in labor shortages during the harvest period, mechanization of cotton harvest was resorted to. In Nicaragua, the number of mechanical cotton pickers increased from 13 in 1963 to 200 in 1967 , and about 20 percent of the crop was mechanically harvested in the latter year. In general, growth of export crop production has provided little increase in employment, and has shifted some workers from year-round to more precarious seasonal employment.

Larger farms in coffee, sugar, and bananas have their own processing facilities, but these facilities also serve as market and processing outlets for independent farm producers. In the case of bananas, the integrated firm also has market control, and when demand is 10 in international markets, purchases are reduced from independent farm producers. 
In EI Salvador some large farms, formerly producing cotton, moved into the production of food crops following a decline in cotton acreage. After 1964 cotton acreage contracted due to declining international prices and increasing costs (larger costs of controlling increasing pest infestation). About two-thirds of this acreage was shifted to crops, mostly corn, with some rice, sorghum, and kenaf, while the remainder reverted to natural pasture. This increase in food grain production on large farms accounted for about half of the increase in corn and rice production in EI Salvador in 1966-67.

The shift of larger farms from cotton to food production had little impact on employment, since mechanized farming was used in both cases. What is significant is that this increase might have come from smaller farms which have traditionally produced corn and rice with much more labor-intensive methods. In this case public policies encouraged increases in food production from the larger farms by credit and technical assistance programs and by contracting for supply of food crops at supported prices primarily with the larger faims.

A similar expansion into new markets was made by banana growing plantations. This expansion was partly motivated by demand stimulated by the formation of the Central American Common Market. Since the formation of the Common Market, United Fruit Company has made major investments in the oils and fat industry. These investments have made it profitable for the company to diversify its commercial production into African palm, beef cattle, basic grains for the regional market, and pineapples.

\section{Implications}

In the first part of this paper I argued that small farms can efficiently participate in development if service institutions are available. The illustrative cases show the possibilities and difficulties of development strategies 
based on small farms.

A development approach based on small farms seems to be a long-range process aided by vigorous development of other sectors of the economy and by the gradual creation and improvement of service institutions. Where both of these conditions are met, as in nineteenth-century Denmark, a dualistic agriculture was transformed into an agricultural sector dominated by family farms. Danish agriculture in the 1870s, in terms of unequal distribution of landownership and differences in technology used on large and small farms, was probably more dualistic than in India and Pakistan before the Green Revolution, and probably less dualistic than agriculture in Latin America.

Under present conditions in less developed countries, the drift of events seems to favor the emergence of dualism and agricultural development based on large farms in cases where the agricultural sector is already dualistic. Attractive opportunities in agriculture created by new technology and the availability of mechanization (tractors) which makes large-scale operations possible provide incentives to larger farmers. This is illustrated both in the Pakistani and Central American cases. The Central American case also shows additional factors favoring large farms. In this region processing facilities for coffee, sugar, and bananas are largely integrated with crop production on large farms, and no forces seem to be operating to create a service sector available to all farmers, as was the case in Denmark. The Central American case also shows the much more rapid thrust of larger farms to preempt new market opportunities, both in the case of cotton and to meet increased domestic demand for food crops, and it illustrates the tendency of governments to supplement the production facilities and infrastructure existing on large farms; credit and price supports for food crops were primarily available to the larger farms. 
Thus, where small and large farms coexist, development of small farms seems to demand a vigorous entrepreneurship in creating a service sector, an entrepreneurship that has to come from government agencies and cooperative efforts of farmers. This effort also needs sufficient time for trial and error improvements in the service agencies that are being created. Research in this area needs to be concerned with the problems of creating and operating a service sector, and not only with the comparative efficiency of different sizes of farm.

The creation of a service sector for small farms in a dualistic agriculture may be too difficult to achieve. Then, the necessary conditions for opening opportunities for small farmers may be land reforms which establish a much more egalitarian distribution of sizes of farms.* In the transformed situation there will be no alternatives to developing technology and service institutions to serve small farmers. In addition, private marketing and processing firms can also be expected to develop and not so much needs to depend on public programs. An example of this is the rebuilding of the marketing system after land reforms in Bolivia described by Clark $(2,3)$. Before the reform the landowner transferred the bulk of the marketable surplus from his hacienda to his own warehouse in town. After the reform new market towns grew up in the countryside within reach of the peasants and these were frequented by itinerant truckers who transported the produce to cities. Another illustration is the introduction of tubewells in the Comilla District of Bangladesh. In this case farms were much smaller and distribution of farm sizes more equal than in Pakistan, so that very few of the farmers could invest in wells of their own. Instead tubewells were installed by village cooperative societies. As a result irrigation water was equally

\footnotetext{
*Another possibility, which I have not attempted to discuss, may be cooperative farming.
} 
available to all members of cooperatives regardless of their size of farm (7). In conclusion, one additional issue needs to be considered. The argument above consists of two parts: 1) that a family farm agriculture combined with service institutions can be an efficient way of organizing the agricultural sector, but 2) that in many less developed countries, the development of agriculture is based on larger farmers, and it seems difficult to involve smaller farmers, even when there is a will to do so. In addition, I am not asserting that development based on larger farmers is inefficient in terms of either the ability to obtain required production increases or in terms of the input costs of increasing output. What, then, are the disadvantages of relying on the response of larger farmers, or the advantages of basing development on smaller farmers?

The issues in this question concern the possibility of premature displacement of labor from agriculture. The agricultural sector shelters many people for whom employment in the rest of the economy is not available. A development strategy based on larger farmers vests in them the decisions about choice of technology, factor proportions, and labor and tenure arrangements $(8,16)$. Some of the likely outcomes include excessive adoption of labor-saving capital, decrease in employment, and a shift from tenants and permanent workers to a greater use of temporary seasonal workers.

What is at issue is the manner in which changing conditions are transmitted by the tenure system into push and pull factors affecting lives of rural people. With development dominated by larger farmers, the new opportunities as well as factor market imperfections (credit and foreign exchange policies as well as surplus of labor) become push factors displacing people from rural employment. With peasant proprietorship the same conditions become pull factors: opportunities to use new technology and new employment opportunities outside of 
agriculture. Some farmers respond to these opportunities while those who have no alternatives or who cannot or are not ready to utilize the new technology at least have access to subsistence. An agriculture of landowning peasants has a much greater capacity to absorb increases in population, without creating barriers to out-migration when employment opportunities appear elsewhere. Thus an agricultural sector organized into small farms can satisfy two important requirements of the early stages of development: it can create employment and absorb people for whom alternatives do not exist elsewhere, and it can provide the necessary increases in production if required service institutions are developed. 


\section{$\underline{\text { References }}$}

1. Brewster, John M., "The Machine Process in Agriculture and Industry." Journal of Farm Economics. Vol. 32, No. 1. February 1950.

2. Clark, Ronald J., "Land Reform and Peasant Market Participation in the Northern Highlands of Bolivia." Land Economics. Vol. 44.1968.

3. "Agrarian Reform, Bolivia." Chapter 7 in Land Reform in Latin America, Issues and Cases, Peter Dorner, editor. Land Economics Monographs No. 3. Madison, Wisconsin 1971.

4. Dorner, Peter and Quiros, Rodolfo. Structural-Institutional Dualism in Central America's Economic Development. Unpublished manuscript, Land Tenure Center. University of Wisconsin, 1972.

5. Falcon, Walter P., "The Green Revolution, Generations of Problems." American Journal of Agricultural Economics. Vol. 52. December 1970.

6. Gotsch, Carl H., The Distributive Impact of Agricultural Growth: Low Income Farmers and the "System" (A Case Study of Sahiwal District, West Pakistan). Seminar on Small Farmer Development Strategies. Agricultural Development Council and Ohio State University. September 13-15, 1971.

7. "Technical Change and the Distribution of Income in Rural Areas." American Journal of Agricultural Economics. Vol. 54, No. 2. May 1972.

8. Johnston, Bruce F. and Cownie, J., "The Seed-Fertilizer Revolution and Labor Force Absorption." American Economic Review. Vol. 59. September 1969.

9. Kanel, Don., "Size of Farm and Economic Development." Indian Journal of Agricultural Economics. Vol. 22, No. 2. April-June 1967.

10. "Land Reform as a Policy Issue in the Modernization of Traditional Societies." Chapter 2 in Land Reform in Latin America, Issues and Cases, Peter Dorner, editor. Land Economics Monographs No. 3. Madison, Wisconsin 1971.

11. Quiros G., Rodolfo. Agricultural Development and the Central American Common Market. Land Tenure Center Research Paper No. 50. University of Wisconsin, Madison. January 1973.

12. Agricultural Development in Central America: Its

Origin and Nature. Land Tenure Center Research Paper No. 49. University of Wisconsin, Madison. January 1973. 
13. Quiros G., Rodolfo. Agricultural Development and Economic Integration in Central America. Ph.D. Thesis. Department of Agricultural Economics. University of Wisconsin, Madison. 1971.

14. Schultz, T. W. "Economic Growth from Traditional Agriculture." Agricultural Sciences for the Developing Nations. Publication No. 76, American Association for the Advancement of Science. Washington, D. C. 1964.

15. Skrubbeltrang, F., Agricultural Development and Rural Reform in Denmark. Agricultural studies No. 22, Food and Agriculture Organization. Rome 1953.

16. Thiesenhusen, William C., Technological Change and Income Distribution in Latin American Agriculture. ITC No. 78, Land Tenure Center, University of Wisconsin, Madison. August 1971. 